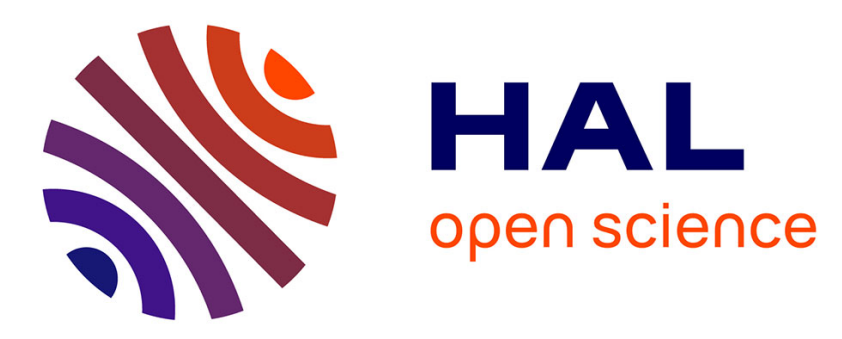

\title{
Small molecular push-pull donors for organic photovoltaics: effect of the heterocyclic $\pi$-spacer
}

Antoine Labrunie, Yue Jiang, François Baert, Antoine Leliège, Jean Roncali, Clément Cabanetos, Philippe Blanchard

\section{- To cite this version:}

Antoine Labrunie, Yue Jiang, François Baert, Antoine Leliège, Jean Roncali, et al.. Small molecular push-pull donors for organic photovoltaics: effect of the heterocyclic $\pi$-spacer. RSC Advances, 2015, 5 (124), pp.102550-102554. 10.1039/c5ra21958b . hal-02889627

\section{HAL Id: hal-02889627 \\ https://univ-angers.hal.science/hal-02889627}

Submitted on 4 Jul 2020

HAL is a multi-disciplinary open access archive for the deposit and dissemination of scientific research documents, whether they are published or not. The documents may come from teaching and research institutions in France or abroad, or from public or private research centers.
L'archive ouverte pluridisciplinaire HAL, est destinée au dépôt et à la diffusion de documents scientifiques de niveau recherche, publiés ou non, émanant des établissements d'enseignement et de recherche français ou étrangers, des laboratoires publics ou privés. 


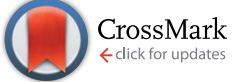

Cite this: RSC Adv., 2015, 5, 102550

Received 20th October 2015 Accepted 11th November 2015

DOI: $10.1039 / c 5 r a 21958 b$

www.rsc.org/advances

\section{Small molecular push-pull donors for organic photovoltaics: effect of the heterocyclic $\pi$-spacer $\dagger$}

\author{
Antoine Labrunie, $\dot{t}^{\mathrm{a}}$ Yue Jiang, $\dot{t}^{\mathrm{ab}}$ François Baert, ${ }^{a}$ Antoine Leliège, ${ }^{a}$ Jean Roncali, ${ }^{a}$
} Clément Cabanetos $^{\star a}$ and Philippe Blanchard ${ }^{\star a}$
A series of (D- $\pi-A)$ small push-pull molecules involving a triphenylamine electron-rich group (D) connected to a dicyanovinyl electrondeficient unit (A) through different chalcogenophene type $\pi$ connectors has been synthesized. Optical and electrochemical results reveal that the replacement of furan by thiophene and selenophene leads to a progressive decrease of the optical band gap of the material and to a parallel increase of hole mobility and power conversion efficiency (PCE). Thus, a PCE of $3.33 \%$ has been obtained for a simple air-processed solar cell involving the selenophene-based donor and the $[6,6]$-phenyl- $C_{61}$-butyric acid methyl ester $\left(\mathrm{PC}_{61} \mathrm{BM}\right)$ as the acceptor.

\section{Introduction}

Over the past decades, organic solar cells (OSCs) have generated a considerable research effort due to their lightness, flexibility, low environmental impact and potential low cost of organic materials. ${ }^{1,2}$ Recent progress in device fabrication and material engineering have led to remarkable progress with power conversion efficiencies (PCE) now exceeding the symbolic value of $10 \% .^{3-5}$

However, beyond striving for improved PCEs, the development of active materials by simple, clean, cost-effective, efficient and scalable syntheses is a mandatory condition for future industrial production. ${ }^{6-8}$ Owing to their well-defined chemical structure, molecularly active materials present the advantages of a better reproducibility of synthesis and purification and a more precise analysis of the structure-property relationships

${ }^{a}$ CNRS UMR 6200, MOLTECH-Anjou, University of Angers, 2 Bd Lavoisier, 49045 Angers, France. E-mail: clement.cabanetos@univ-Angers.fr; Philippe.blanchard@ univ-Angers.fr

${ }^{b}$ South China University of Technology, 381 Wushan Rd, Tianhe, Guangzhou, Guangdong, China

$\dagger$ Electronic supplementary information (ESI) available. See DOI: 10.1039/c5ra21958b

\$ Both authors contributed equally to this work. compared to polydisperse polymers..$^{9-11}$ Among them, DonorConnector-Acceptor (D- $\pi-\mathrm{A}$ ) type push-pull molecules based on arylamines donor blocks represent interesting molecular donors that combine synthetic accessibility, simplicity and efficiency. ${ }^{6,12-15}$ Indeed, TPA-T-DCV (Fig. 1), prepared in good yields in a few synthetic steps, has been over the past few years an interesting working structure to investigate the effects of various structural variations such as (i) the covalent bridging of the dicyanovinyl (DCV) group, ${ }^{\mathbf{1 6}}$ (ii) its replacement by other electron-withdrawing units, ${ }^{17}$ (iii) the substitution of one phenyl ring of TPA by fused ring systems or aliphatic chains, ${ }^{18,19}$ or (iv) the drastic size reduction to assess the limit of simplification. ${ }^{20}$

As a further step of this systematic analysis of structureproperties relationships, we report here on the effect of the nature of the heterocyclic $\pi$-connector by the synthesis, characterization and photovoltaic evaluation of the furan (TPA-FDCV) and selenophene (TPA-S-DCV) analogues of TPA-T-DCV (Fig. 1).

Indeed, while several articles deal with the effect of the replacement of the thiophene ring by other chalcogenophene in conjugated polymers for OSCs, ${ }^{21-25}$ only few examples of molecular donors, especially incorporating the selenophene ring, have been reported..$^{26-29}$

\section{Results and discussions}

The synthesis of the three molecules is depicted in Scheme 1.

5-Formylfuran-2-boronic acid was engaged in a Suzuki crosscoupling reaction with the commercially available 4-bromotriphenylamine 1 affording the carbonyl compound $4^{30}$ In parallel, the thiophene and selenophene analogues 5 and $\mathbf{6}$ were prepared by a two-step procedure involving a Stille crosscoupling of 4-bromotriphenylamine $\mathbf{1}$ and the appropriate trimethyl stannylated chalcogenophene, followed by a VilsmeierHaack formylation with $\mathrm{POCl}_{3} / \mathrm{DMF}{ }^{\mathbf{1 6}}$ Finally, a Knoevenagel condensation between malononitrile and the carbaldehydes $\mathbf{4}$, $\mathbf{5}$ or $\mathbf{6}$ led to the target products TPA-F-DCV, TPA-T-DCV and TPA-S-DCV respectively. 


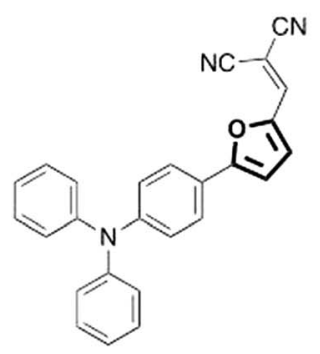

TPA-F-DCV

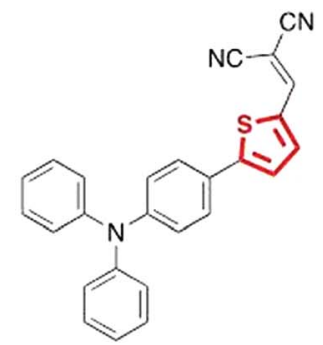

TPA-T-DCV

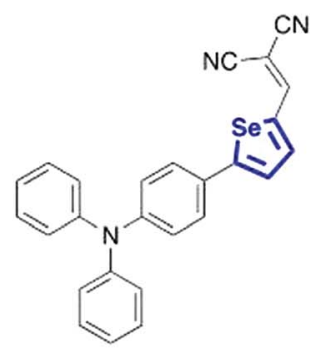

TPA-S-DCV

Fig. 1 Chemical structure of the $D-\pi-A$ target molecules.

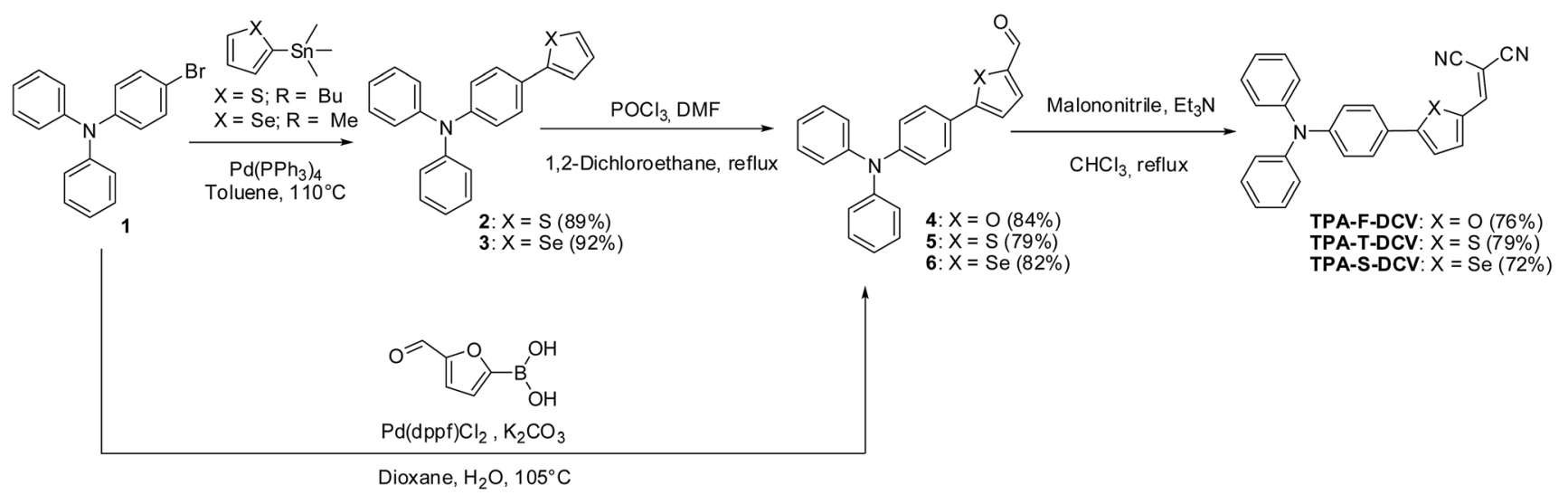

Scheme 1 Synthetic route to TPA-F-DCV, TPA-T-DCV and TPA-S-DCV.

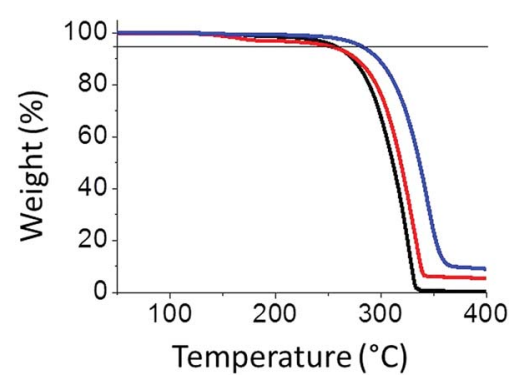

Fig. 2 Thermogravimetric analysis of TPA-F-DCV (black), TPA-T-DCV (red) and TPA-S-DCV (blue) recorded at $5{ }^{\circ} \mathrm{C} \mathrm{min}^{-1}$ under $\mathrm{N}_{2}$.
The compounds show good solubility in common organic solvents and their thermal stabilities were assessed by thermogravimetric analysis (Fig. 2).

The furan and thiophene derivatives exhibit a comparable decomposition temperature $\left(T_{\mathrm{d}}\right)$ of $c a .255^{\circ} \mathrm{C}$. However, introducing a selenium atom slightly increases $T_{\mathrm{d}}$ since a $5 \%$ weight loss was recorded at ca. $280^{\circ} \mathrm{C}$ for TPA-S-DCV.

UV-Vis absorption spectra were recorded on chloroform solutions and on films spin-cast on glass.

The spectrum of all compounds shows an intense absorption band with a maximum $\left(\lambda_{\max }\right)$ around $500 \mathrm{~nm}$ assigned to an
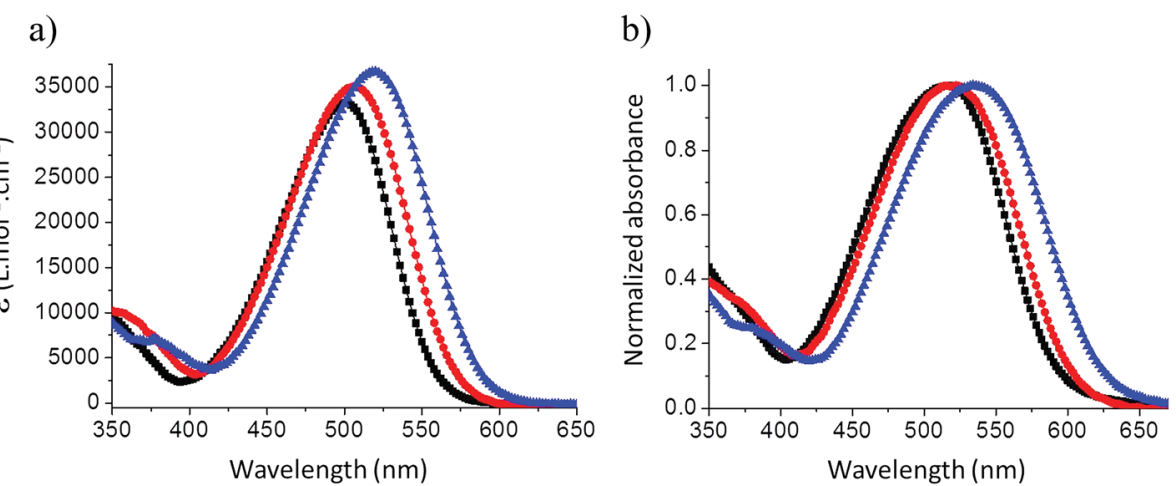

Fig. 3 UV-Vis absorption spectra of TPA-F-DCV (black squares), TPA-T-DCV (red circles) and TPA-S-DCV (blue triangles) in chloroform (a) and as thin film on glass (b). 
Table 1 UV-Vis absorption data

\begin{tabular}{lllllll}
\hline Compound & $\lambda_{\max }(\mathrm{nm})$ solution & $\varepsilon\left(\mathrm{M}^{-1} \mathrm{~cm}^{-1}\right)$ & $\lambda_{\text {onset }}(\mathrm{nm})$ solution & $\lambda_{\max }(\mathrm{nm})$ film & $\lambda_{\text {onset }}(\mathrm{nm})$ film & $E_{\mathrm{g}}^{\text {opt }}(\mathrm{eV})$ film \\
\hline TPA-F-DCV & 499 & 33000 & 560 & 517 & 595 & 2.08 \\
TPA-T-DCV & 505 & 35000 & 572 & 523 & 606 \\
TPA-S-DCV & 520 & 36800 & 587 & 535 & 630 & 2.04 \\
& & & & & 1.96
\end{tabular}

Table 2 Electrochemical data for the target compounds $\left(0.5 \mathrm{mM}\right.$ in $0.10 \mathrm{M} \mathrm{Bu}_{4} \mathrm{NPF}_{6} / \mathrm{CH}_{2} \mathrm{Cl}_{2}$, scan rate $100 \mathrm{mV} \mathrm{s}{ }^{-1}$, Pt working and counter electrodes, ref. SCE)

\begin{tabular}{|c|c|c|c|c|c|c|c|}
\hline Compound & $E_{\mathrm{pa}}^{1}(\mathrm{~V})$ & $E_{\text {Ox/onset }}(\mathrm{V})$ & $E_{\mathrm{pc}}^{1}(\mathrm{~V})$ & $E_{\text {Red/onset }}(\mathrm{V})$ & $\mathrm{HOMO}^{a}(\mathrm{eV})$ & $\mathrm{LUMO}^{b}(\mathrm{eV})$ & $\Delta E^{\text {elec }}(\mathrm{eV})$ \\
\hline TPA-F-DCV & 0.98 & 0.86 & -1.24 & -1.07 & -5.85 & -3.92 & 1.93 \\
\hline TPA-T-DCV & 1.01 & 0.87 & -1.20 & -1.05 & -5.86 & -3.94 & 1.92 \\
\hline
\end{tabular}

internal charge transfer (ICT) from the TPA moiety to the electron-deficient DCV group (Fig. 3). Replacement of the furan spacer by thiophene and selenophene leads to a progressive bathochromic shift of $\lambda_{\max }$ from 499 to $520 \mathrm{~nm}$ with a parallel

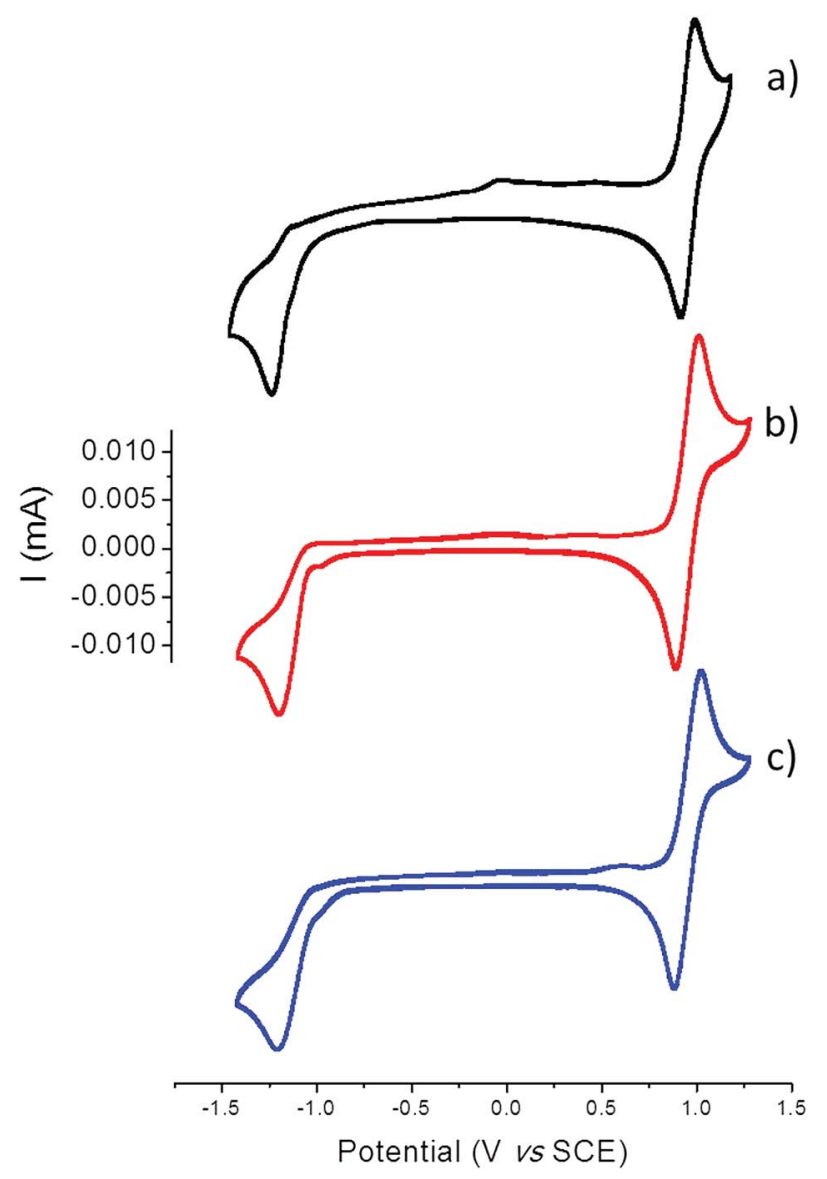

Fig. 4 Cyclic voltammograms of TPA-F-DCV (black), TPA-T-DCV (red) and TPA-S-DCV (blue) $0.5 \mathrm{mM}$ in $0.1 \mathrm{M} \mathrm{Bu}_{4} \mathrm{NPF}_{6} / \mathrm{CH}_{2} \mathrm{Cl}_{2}$, scan rate $100 \mathrm{mV} \mathrm{s}^{-1}$, Pt working and counter electrodes, ref. SCE. increase of the molar extinction coefficient $(\varepsilon)$ from 33000 to $36800 \mathrm{M}^{-1} \mathrm{~cm}^{-1}$ (Table 1), in agreement with previous observations (Fig. 3). ${ }^{23,31,32}$ Broader absorption bands and red-shifted absorption edges with onsets at ca. $595 \mathrm{~nm}, 606 \mathrm{~nm}$ and $630 \mathrm{~nm}$ corresponding to optical band gaps $\left(E_{\mathrm{g}}^{\mathrm{opt}}\right)$ of $2.08 \mathrm{eV}, 2.04 \mathrm{eV}$ and $1.96 \mathrm{eV}$ for TPA-F-DCV, TPA-T-DCV and TPA-S-DCV respectively were observed on thin films (Fig. 3b).

The electrochemical properties of the three molecules have been analyzed by cyclic voltammetry in dichloromethane solution in the presence of $\mathrm{Bu}_{4} \mathrm{NPF}_{6}$ as the supporting electrolyte. Data are summarized in Table 2.

The cyclic voltammogram (CV) of all compounds shows a reversible one-electron oxidation wave, assigned to the formation of a stable radical cation (Fig. 4). While the CVs of TPA-T-DCV and TPA-S-DCV show comparable anodic peak potentials at $E_{\mathrm{pa}}=1.01 \mathrm{~V}$, the furan derivative presents a slight negative shift of $E_{\mathrm{pa}}$ to $0.98 \mathrm{~V}$ indicative of an increase of the HOMO level. In the negative potentials region, the $\mathrm{CV}$ of all donors exhibits an irreversible reduction process with cathodic potential peak at $E_{\mathrm{pc}}=-1.24 \mathrm{~V}$ for TPA-F-DCV and $-1.20 \mathrm{~V}$ for both the thiophene and selenophene compounds. HOMO and LUMO levels were calculated respectively from the onsets of oxidation and reduction waves (Table 2 ).

A slight reduction of the electrochemical gap $\left(\Delta E^{\text {elec }}\right)$ is observed from the furan derivative $(1.93 \mathrm{eV})$ to the selenophene one $(1.88 \mathrm{eV})$, in agreement with optical data. Electrochemical data also show that this decrease of $\Delta E^{\text {elec }}$ is mainly associated to the lowering of the LUMO energy levels when varying the heteroatom of the chalcogenophene from oxygen to selenium whereas the HOMO energy levels remains relatively unaffected.

To gain further insight into the electronic properties, the frontier orbitals and energy levels of the compounds have been investigated by theoretical calculations performed with Gaussian 09 program using Becke's three-parameter gradientcorrected functional (B3LYP) with the 6-31G(d,p) basis set (Fig. 5).

The optimized geometries and computed electronic structures at the observed minima reveal that the LUMO is strongly 


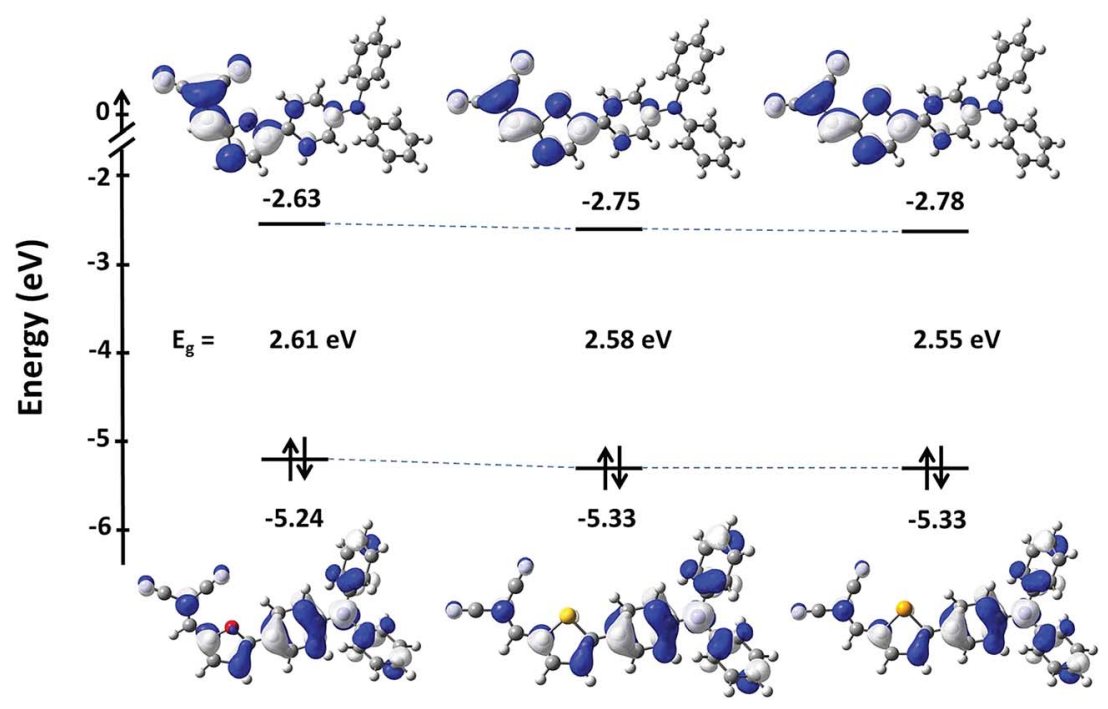

Fig. $5 \mathrm{HOMO}$ and LUMO energy levels and their representations for TPA-F-DCV (left), TPA-T-DCV (middle) and TPA-S-DCV (right) after optimization with Gaussian 09 at the B3LYP/6-31G(d,p) level of theory.

Table 3 Photovoltaic properties of TPA-F-DCV, TPA-T-DCV and TPA-S-DCV blended with PC $_{61} B M(1: 2 \mathrm{w} / \mathrm{w})$

\begin{tabular}{llllll}
\hline Donor & $\begin{array}{l}V_{\mathrm{oc}} \\
(\mathrm{V})\end{array}$ & $\begin{array}{l}J_{\mathrm{sc}} \\
\left.(\mathrm{mA} \mathrm{cm})^{-2}\right)\end{array}$ & $\begin{array}{l}\mathrm{FF} \\
(\%)\end{array}$ & $\begin{array}{l}\mathrm{PCE}_{\text {max/ave }}{ }^{a} \\
(\%)\end{array}$ & $\begin{array}{l}\mu_{\mathrm{h}} \\
\left(\mathrm{cm}^{2} \mathrm{~V}^{-1} \mathrm{~s}^{-1}\right)\end{array}$ \\
\hline TPA-F-DCV & 0.97 & 5.28 & 38.9 & $2.50 / 2.23$ & $8.1 \times 10^{-6}$ \\
TPA-T-DCV & 0.97 & 6.53 & 37.9 & $3.00 / 2.86$ & $1.2 \times 10^{-5}$ \\
TPA-S-DCV & 0.95 & 7.15 & 39.2 & $3.33 / 3.17$ & $1.7 \times 10^{-5}$
\end{tabular}

${ }^{a}$ Average value recorded over 18 devices.

localized on the five-membered ring-DCV block whereas the HOMO is mainly distributed on the TPA-spacer. In addition, the geometry of TPA-F-DCV presents the smallest dihedral angle between the phenyl ring and the heterocycle $\left(1.4^{\circ}\right.$ vs. $19.6^{\circ}$ and $17.6^{\circ}$ for TPA-T-DCV and TPA-S-DCV respectively) ensuring a better planarity of the structure. The calculated values of the HOMO and LUMO levels are consistent with optical and electrochemical results.

The photovoltaic properties of the three donors have been evaluated in bulk heterojunction solar cells of $0.27 \mathrm{~cm}^{2}$ of configuration: ITO/PEDOT:PSS (ca. $40 \mathrm{~nm}$ )/Donor: $\mathrm{PC}_{61} \mathrm{BM}$ blend/LiF $(1 \mathrm{~nm}) / \mathrm{Al}(120 \mathrm{~nm})$. Except for $\mathrm{LiF}$ and aluminum depositions, the cells were fabricated in ambient atmosphere. Table 3 gathers the photovoltaic parameters of these devices and Fig. 6a shows the best current density-voltage $(J-V)$ characteristics measured under AM 1.5 simulated solar illumination $\left(80 \mathrm{~mW} \mathrm{~cm}^{-2}\right)$.

The high open-circuit voltages $\left(V_{\mathrm{oc}} \sim 1.0 \mathrm{~V}\right)$ are consistent with the low-lying HOMO level of the donors resulting in a large offset with the LUMO level of $\mathrm{PC}_{61} \mathrm{BM}$. Although comparable $V_{\mathrm{oc}}$ and fill factors (FF) values are obtained for all cells, the shortcircuit current-density $\left(J_{\mathrm{sc}}\right)$ progressively increases from TPA-FDCV to TPA-S-DCV leading to a parallel increase of PCE from
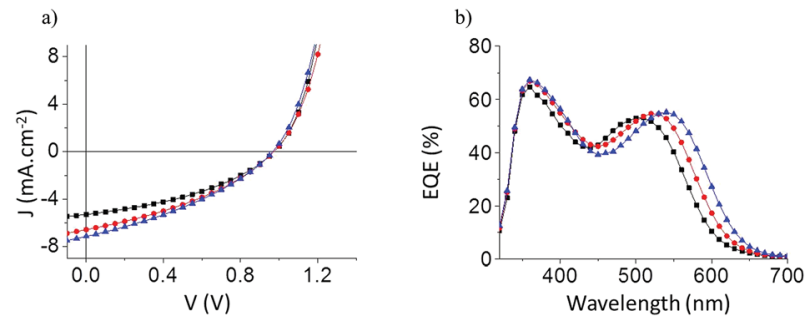

Fig. $6 \mathrm{~J}-V$ characteristics and EQE curves of TPA-F-DCV (black squares), TPA-T-DCV (red circles) and TPA-S-DCV (blue triangles) based OSCs.

2.50 to $3.33 \%$ (Table 3 ). This trend is confirmed by external quantum efficiency (EQE) measurements performed under monochromatic irradiation (Fig. 6b).

Thus, varying the heteroatom from oxygen to selenium results in a slight extension of the contribution of the donor in the long wavelengths region with a maximum photon-to-current

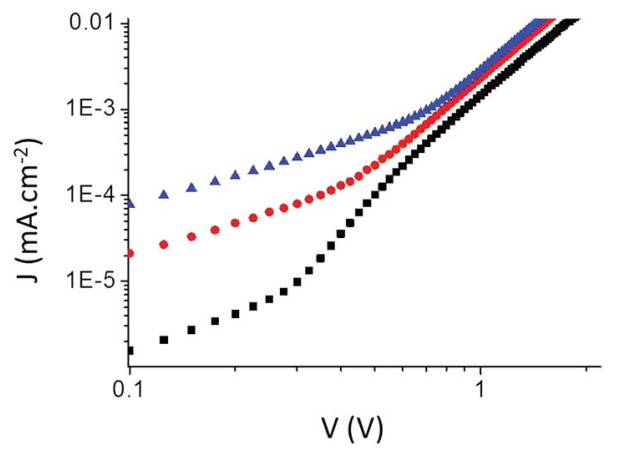

Fig. $7 \quad J-V$ characteristics of hole only devices ITO/PEDOT:PSS/TPAF-DCV (black squares), TPA-T-DCV (red circles) or TPA-S-DCV (blue triangles)/Au. 
conversion of $52 \%$ at $504 \mathrm{~nm}, 54 \%$ at $523 \mathrm{~nm}$ and $55 \%$ at 540 nm for TPA-F-DCV, TPA-T-DCV and TPA-S-DCV respectively.

The hole-mobility of the materials $\left(\mu_{\mathrm{h}}\right)$ was determined using the space-charge limited current (SCLC) method on hole-only devices (Fig. 7).

As shown in Table 3, the furan-containing molecule exhibits the lowest mobility (of $c a .8 .1 \times 10^{-6} \mathrm{~cm}^{2} \mathrm{~V}^{-1} \mathrm{~s}^{-1}$ ) and the selenophene derivative the highest $\left(1.7 \times 10^{-5} \mathrm{~cm}^{2} \mathrm{~V}^{-1} \mathrm{~s}^{-1}\right)$. These results, in agreement with the $J_{\mathrm{sc}}$ trend, can be correlated to the improved orbitals overlap of heavier chalcogen heteroatoms resulting in enhanced intermolecular electronic interactions.

\section{Conclusion}

Triphenylamine based D- $\pi-\mathrm{A}$ type small molecular donors with three different five-membered heterocycles as $\pi$-conjugating connector have been synthesized. Replacement of furan by thiophene and selenophene produces a small reduction of the band gap and an improvement of the hole-mobility and photovoltaic conversion efficiency of the donor. In addition to the synthetic accessibility (i.e., three steps from commercially available materials), promising power conversion efficiencies above $3.0 \%$ were obtained with simple $\mathrm{BHJ}$ solar cells processed in ambient atmosphere with $\mathrm{PC}_{61} \mathrm{BM}$ as acceptor. Further device optimization (morphology, additives, and interfaces) can be expected to significantly improve these preliminary results.

\section{Acknowledgements}

The RFI LUMOMAT is also acknowledged for the PhD grant of A. Labrunie. The Chinese Government Scholarship (CGC) program is acknowledged for the Ph-D grant of Y. Jiang and the Ministère de la Recherche is thanked for the Ph-D grant of F. Baert. The PIAM (Plateforme d'Ingénierie et Analyses Moléculaires) of the University of Angers is thanked for the characterization of organic compounds. Finally, this paper is dedicated to Dr Errol Blart on the occasion of his $50^{\text {th }}$ birthday.

\section{References}

1 K. A. Mazzio and C. K. Luscombe, Chem. Soc. Rev., 2015, 44, 78-90.

2 F. C. Krebs, N. Espinosa, M. Hösel, R. R. Søndergaard and M. Jørgensen, Adv. Mater., 2014, 26, 29-39.

3 S.-H. Liao, H.-J. Jhuo, P.-N. Yeh, Y.-S. Cheng, Y.-L. Li, Y.-H. Lee, S. Sharma and S.-A. Chen, Sci. Rep., 2014, 4, 6813.

4 J. You, C.-C. Chen, Z. Hong, K. Yoshimura, K. Ohya, R. Xu, S. Ye, J. Gao, G. Li and Y. Yang, Adv. Mater., 2013, 25, 3973-3978.

5 Y. Liu, J. Zhao, Z. Li, C. Mu, W. Ma, H. Hu, K. Jiang, H. Lin, H. Ade and H. Yan, Nat. Commun., 2014, 5, 5293.

6 J. Roncali, P. Leriche and P. Blanchard, Adv. Mater., 2014, 26, 3821-3838.

7 R. Po, G. Bianchi, C. Carbonera and A. Pellegrino, Macromolecules, 2015, 48, 453-461.

8 R. Po, A. Bernardi, A. Calabrese, C. Carbonera, G. Corso and A. Pellegrino, Energy Environ. Sci., 2014, 7, 925-943.
9 J. Roncali, Acc. Chem. Res., 2009, 42, 1719-1730.

10 A. Mishra and P. Bäuerle, Angew. Chem., Int. Ed., 2012, 51, 2020-2067.

11 M. T. Lloyd, J. E. Anthony and G. G. Malliaras, Mater. Today, 2007, 10, 34-41.

12 J. W. Choi, C.-H. Kim, J. Pison, A. Oyedele, D. Tondelier, A. Leliege, E. Kirchner, P. Blanchard, J. Roncali and B. Geffroy, RSC Adv., 2014, 4, 5236-5242.

13 V. Malytskyi, J.-J. Simon, L. Patrone and J.-M. Raimundo, RSC Adv., 2015, 5, 354-397.

14 P. F. Xia, X. J. Feng, J. Lu, S.-W. Tsang, R. Movileanu, Y. Tao and M. S. Wong, Adv. Mater., 2008, 20, 4810-4815.

15 V. Steinmann, N. M. Kronenberg, M. R. Lenze, S. M. Graf, D. Hertel, K. Meerholz, H. Bürckstümmer, E. V. Tulyakova and F. Würthner, Adv. Energy Mater., 2011, 1, 888-893.

16 A. Leliege, R. C.-H. Le, M. Allain, P. Blanchard and J. Roncali, Chem. Commun., 2012, 48, 8907-8909.

17 V. Jeux, O. Segut, D. Demeter, O. Alévêque, P. Leriche and J. Roncali, in ChemPlusChem, Wiley-VCH Verlag, Weinheim, 2015, vol. 80, pp. 697-703.

18 S. Mohamed, D. Demeter, J.-A. Laffitte, P. Blanchard and J. Roncali, Sci. Rep., 2015, 5, 9031.

19 Y. Jiang, C. Cabanetos, M. Allain, P. Liu and J. Roncali, J. Mater. Chem. C, 2015, 3, 5145-5151.

20 V. Jeux, D. Demeter, P. Leriche and J. Roncali, RSC Adv., 2013, 3, 5811-5814.

21 W.-H. Chang, L. Meng, L. Dou, J. You, C.-C. Chen, Y. Yang, E. P. Young, G. Li and Y. Yang, Macromolecules, 2015, 48, 562-568.

22 J. Warnan, A. El Labban, C. Cabanetos, E. T. Hoke, P. K. Shukla, C. Risko, J.-L. Brédas, M. D. McGehee and P. M. Beaujuge, Chem. Mater., 2014, 26, 2299-2306.

23 R. S. Ashraf, I. Meager, M. Nikolka, M. Kirkus, M. Planells, B. C. Schroeder, S. Holliday, M. Hurhangee, C. B. Nielsen, H. Sirringhaus and I. McCulloch, J. Am. Chem. Soc., 2015, 137, 1314-1321.

24 A. T. Yiu, P. M. Beaujuge, O. P. Lee, C. H. Woo, M. F. Toney and J. M. J. Fréchet, J. Am. Chem. Soc., 2012, 134, 2180-2185.

25 Y. S. Park, Q. Wu, C.-Y. Nam and R. B. Grubbs, Angew. Chem., Int. Ed., 2014, 53, 10691-10695.

26 S. Haid, A. Mishra, M. Weil, C. Uhrich, M. Pfeiffer and P. Bäuerle, Adv. Funct. Mater., 2012, 22, 4322-4333.

27 K. A. Mazzio, M. Yuan, K. Okamoto and C. K. Luscombe, ACS Appl. Mater. Interfaces, 2011, 3, 271-278.

28 S. Haid, A. Mishra, C. Uhrich, M. Pfeiffer and P. Bäuerle, Chem. Mater., 2011, 23, 4435-4444.

29 J. Hollinger, D. Gao and D. S. Seferos, Isr. J. Chem., 2014, 54, 440-453.

30 J. Liu, K. Wang, X. Zhang, C. Li and X. You, Tetrahedron, 2013, 69, 190-200.

31 Y.-S. Yen, C.-T. Lee, C.-Y. Hsu, H.-H. Chou, Y.-C. Chen and J. T. Lin, Chem.-Asian J., 2013, 8, 809-816.

32 Z. Zeng, Y. Li, J. Deng, Q. Huang and Q. Peng, J. Mater. Chem. A, 2014, 2, 653-662.

33 C. M. Cardona, W. Li, A. E. Kaifer, D. Stockdale and G. C. Bazan, Adv. Mater., 2011, 23, 2367-2371. 